Acta Technologica Agriculturae 1

Nitra, Slovaca Universitas Agriculturae Nitriae, 2018, pp. 24-27

\title{
DIAGNOSTICS OF WINDING DEFORMATION IN A SINGLE-PHASE POWER TRANSFORMER WITH AN UNLOADED TERTIARY WINDING IN OPERATIONAL MODE
}

\author{
Sergey DOROZHKO, Andrey KRIVUNEV* \\ Stavropol State Agrarian University, Russia
}

\begin{abstract}
The presented paper is focused on the development of an algorithm and software implementation of this algorithm into diagnostics of winding deformation in a single-phase power transformer with an unloaded tertiary winding in operational mode. To implement the algorithm, it is necessary to measure instantaneous values of input voltage and current, output voltage and current, and voltage across the unloaded tertiary winding by means of the electric power quality analyzer PQA - 824. This tool is utilized for signal filtering. The inductances of T-shaped equivalent circuit of the transformer were calculated. Relative deviations of the obtained inductance values were determined on the basis of transformer in operation; these deviations were compared with pre-determined set-points. If the inductances deviate from the set-points, the transformer must be repaired. Modern mathematical software package Mathcad 14 is designed to implement the algorithm. As a result of laboratory tests, the error of the proposed algorithm does not exceed $2 \%$ in comparison with the exact method.
\end{abstract}

Keywords: single-phase power transformer; equivalent circuit; windings; operational mode; power quality analyzer

The reliability of electrical equipment largely determines the reliability of power distribution systems. Emergency damage, often accompanied by the destruction of equipment, leads to electric power failure and economic damage. Significant losses occur due to failures of power transformers.

Nearly $50 \%$ of transformer substations of rural distribution network in Russia have reached their expected service life (Makarova, 2012). The annual failure rate of power transformers in these networks is up to $55.2 \%$ due to the turn shortenings in windings (Davidenko et al., 2008). Usually, the turn shorting is a result of windings deformation. A transformer with significant deformation of the windings must be taken out for repair. This step will eliminate the transformer failure. Therefore, the reduction of accident rate of power transformers due to the deformation of windings is an urgent task.

Even nowadays, the evaluation of actual power transformer state according to the results from diagnostic measurements is not simple to perform. Traditional methods for deformation detection (Low Voltage Impulse (LVI) method, Frequency Response Analysis (FRA), reactance measurement, etc.) require switching off the transformer (Chen et al., 2002; Miyazaki et al., 2017; IEEE, 1995). Moreover, for the measurement itself, precision instruments and trained personnel are also essential.

The deformation of the windings can be diagnosed by changes in element parameters of the L-shaped equivalent circuit of the transformer (Dorozhko, 2015) and in parameters of longitudinal branches of the T-shaped equivalent circuit of the transformer without disconnection from the electric network (Zasypkin and Dorozhko, 1995). The following papers also try to find a solution to this issue: $\mathrm{Xu}$ and $\mathrm{Li}$ (1998), Reddy and Rajpurohit (2014), Can et al. (2016). Taking into account the impacts of neglecting this problem, it is necessary to carry out such diagnostic measurements on all transformers in agricultural enterprises and rural distribution networks (Prístavka and Bujna, 2014).

In power networks, both three-phase transformers and single-phase transformers are used; however, there is considerably lower number of three-phase transformers in operation. Therefore, it is reasonable to consider the performance of the transformer diagnostics only for singlephase transformers and subsequent application of results in three-phase transformers. The aim of the paper is to devise an algorithm and subsequent software implementation of this algorithm into diagnosis of winding deformation in single-phase power transformer with an unloaded tertiary winding in operational mode.

\section{Material and methods}

In order to determine the parameters of T-shaped equivalent circuit elements in a single-phase transformer with unloaded tertiary winding in operational mode, it is necessary to measure the arrays of instantaneous values of input voltage $\left|u_{1}\left(t_{j}\right)\right|(\mathrm{V})$, input current $\left|i_{1}\left(t_{j}\right)\right|(\mathrm{A})$, output voltage $\left|u_{2}\left(t_{j}\right)\right|(\mathrm{V})$, output current $\left|i_{2}\left(t_{j}\right)\right|(\mathrm{A})$ and voltage across the tertiary unloaded winding $\left|u_{3}\left(t_{j}\right)\right|(\mathrm{V})$, where $t_{j}=$ $t_{1}, t_{2}, \ldots t_{N}(\mathrm{~s}) ; N$ - number of samples of instantaneous values within the given period (Fig. 1). The measurements were

Contact address: Andrey Krivunev, Stavropol State Agrarian University, Russia, e-mail: dusikasss26@mail.ru 
performed by means of the electric power quality analyzer PQA - 824 (here and after analyzer) (HT-ITALIA, 2007; Dorozhko, 2011). The analyzer can simultaneously record 4 current signals with accuracy $\pm 0.5 \%$ readings plus $0.06 \%$ full scale clamp and 4 voltage signals with accuracy $\pm 0.5 \%$ readings plus 2 no. of digits. Analog-to-digital converter (ADC) resolution is 256 samples per $50 \mathrm{~Hz}$.

The instantaneous values of output current, output voltage and voltage across the tertiary unloaded winding are reduced to the first side of the transformer:

$\left|i_{2}^{\prime}\left(t_{j}\right)\right|=\frac{W_{2}}{W_{1}}\left|i_{2}\left(t_{j}\right)\right|,\left|u_{2}^{\prime}\left(t_{j}\right)\right|=\frac{W_{1}}{W_{2}}\left|u_{2}\left(t_{j}\right)\right|,\left|u_{3}^{\prime}\left(t_{j}\right)\right|=\frac{W_{1}}{W_{3}}\left|u_{3}\left(t_{j}\right)\right|(1)$

where:

$W_{1}, W_{2}, W_{3}$ - the number of turns of the primary, secondary and tertiary windings of the transformer

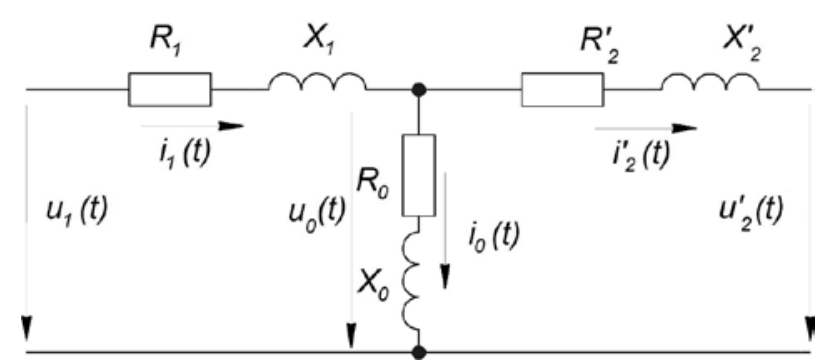

Fig. 1 T-shaped single-phase transformer circuit

$R_{1}$ - active resistance of the primary winding; $X_{1}$ - inductive resistance of the primary winding; $X_{0}$ - inductive resistance magnetizing; $R_{0}$ - resistance to magnetic losses; $R_{2}^{\prime}$ - reduced active resistance of the secondary winding; $X_{2}^{\prime}$ - reduced inductive resistance of the secondary winding

Since there is no current flowing through the tertiary unloaded winding, there is no drop in the voltage due to its resistance. Consequently, the voltage $\left|u_{3}\left(t_{j}\right)\right|$ is proportional to the electromotive force (EMF) of magnetization:

$$
\left|u_{0}\left(t_{j}\right)\right|=\left|u_{3}^{\prime}\left(t_{j}\right)\right|
$$

Using the second Kirchhoff law, the array of voltage instantaneous values on the first longitudinal resistance of the equivalent circuit was determined using the following expression:

$$
\left|\Delta u_{1}\left(t_{j}\right)\right|=\left|u_{1}\left(t_{j}\right)\right|-\left|u_{0}\left(t_{j}\right)\right|
$$

The differentiation of the array of input current instantaneous values at the given period of time was performed using:

$$
\left|\frac{d i_{1}\left(t_{j}\right)}{d t}\right|=\frac{i_{1}\left(t_{j}\right)-i_{1}\left(t_{j-1}\right)}{\Delta t}
$$

where:

$\Delta t \quad$ - sampling interval of the array of instantaneous values of the input current in time, $s$

Since the resistance of the longitudinal branches of the transformer replacement circuit is linear, the known relation for the voltage drop in the circuit with active resistance and inductance will be equal to:

$$
u_{1}\left(t_{j}\right)=R_{1} i_{1}\left(t_{j}\right)+L_{1} \frac{d i_{1}\left(t_{j}\right)}{d t}
$$

where:

$R_{1} \quad$ - active resistance of the primary winding

$L_{1} \quad$ - inductance of the primary winding

This equation contains two unknown variables $R_{1}$ and $L_{1}$. The equation applies to the particular time instant $t_{j i}$ therefore, there are several such equations for the given period of time. In order to determine the inductance of the primary winding $L_{1}$, it is necessary to solve the equation for the instants of time $t_{11}$ and $t_{12}$ when $i_{1}\left(t_{j}\right)=0$.

Inductance was calculated using expressions:

$$
\begin{aligned}
& L_{1}\left(t_{11}\right)=\frac{u_{1}\left(t_{11}\right)}{\frac{d i_{1}\left(t_{11}\right)}{d t}}(\mathrm{H}) \\
& L_{1}\left(t_{12}\right)=\frac{u_{1}\left(t_{12}\right)}{\frac{d i_{1}\left(t_{12}\right)}{d t}}(\mathrm{H})
\end{aligned}
$$

Mean values of the primary winding inductive resistance for the period of time were calculated using Eq. (5):

$$
L_{1 a v}=\frac{L_{1}\left(t_{11}\right)+L_{1}\left(t_{12}\right)}{2}
$$

Using the second Kirchhoff law, the array of instantaneous values of voltage on the second longitudinal resistance of the equivalent circuit reduced to the first circuit was determined using the following expression:

$$
\left|\Delta u_{2}^{\prime}\left(t_{j}\right)\right|=\left|u_{0}\left(t_{j}\right)\right|-\left|u_{2}^{\prime}\left(t_{j}\right)\right|
$$

The differentiation of the instantaneous value array of the reduced output current at the given time was performed using expression:

$$
\left|\frac{d i_{2}^{\prime}\left(t_{j}\right)}{d t}\right|=\frac{i_{2}^{\prime}\left(t_{j}\right)-i_{2}^{\prime}\left(t_{j-1}\right)}{\Delta t}
$$

Then time points when $i_{2}\left(t_{j}\right)=0$ (two time points $t_{21}$ and $t_{22}$ ) were recorded.

Subsequently, inductance values were calculated using:

$$
\begin{aligned}
& L_{2}^{\prime}\left(t_{21}\right)=\frac{u_{2}^{\prime}\left(t_{21}\right)}{\frac{d i_{2}^{\prime}\left(t_{21}\right)}{d t}}(\mathrm{H}) \\
& L_{2}^{\prime}\left(t_{22}\right)=\frac{u_{2}^{\prime}\left(t_{22}\right)}{\frac{d i_{2}^{\prime}\left(t_{22}\right)}{d t}}(\mathrm{H})
\end{aligned}
$$

The mean inductive resistance values of the secondary winding for the given period of time were calculated by means of the following formula: 


$$
L_{2 a v}^{\prime}=\frac{L_{2}^{\prime}\left(t_{21}\right)+L_{2}^{\prime}\left(t_{22}\right)}{2}
$$

It was necessary to determine the relative deviations of inductance of the primary winding $\Delta L_{1}=\frac{\left|L_{1 \text { serv }}-L_{1 a v}\right|}{L_{1 s e r v}} \cdot 100 \%$ and inductance of the secondary winding $\Delta L_{2}=\frac{\left|L_{2 s e r v}^{\prime}-L_{2 a v}^{\prime}\right|}{L_{2 s e r v}^{\prime}}$. - $100 \%$ from the values obtained from transformers in operation $L_{1 s e r v}$ and $L_{2 \text { serv }}^{\prime}$ ). Finally, obtained deviations were compared with the set-points. If the inductances deviate from the set-points, the transformer must be repaired.

The numerical differentiation of the array of input current instantaneous values at time $\left|\frac{d i_{1}\left(t_{j}\right)}{d t}\right|$, reduced by the value of output current $\left|\frac{d i_{2}^{\prime}\left(t_{j}\right)}{d t}\right|$, can result in very small values.

The determination of the change in inductive resistance of windings can result in significant errors (Dorozhko and Dubkov, 2010). Further calculations are carried out with filtered signals. According to the foregoing algorithm, a program in modern mathematical packet Mathcad 14 is developed.

In order to verify this algorithm, measurements were performed on the laboratory specimen of T-shaped singlephase transformer with the following technical data: rated power $0.4 \mathrm{~kW}$; primary winding voltage $220 \mathrm{~V}$; secondary winding voltage $230 \mathrm{~V}$; the voltage of unloaded tertiary winding $12 \mathrm{~V}$.

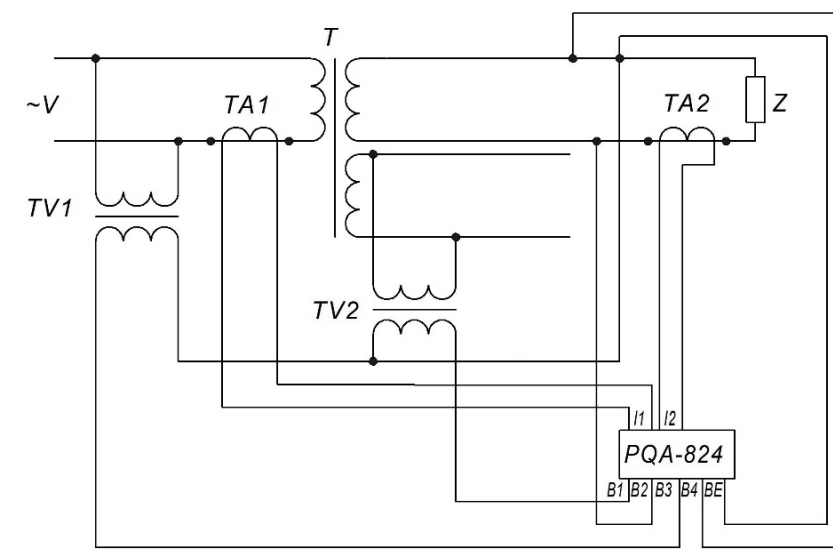

Fig. 2 Diagnostic diagram of winding deformation of singlephase power transformer with unloaded tertiary winding in operational mode

$T V 1, T V 2$ - voltage transformers (accuracy class 0.2 ); TA1, TA2 current transformers (from the kit of electric power quality analyzer PQA - 824, the main reduced error of $1 \%$ ); inputs of electric power quality analyzer PQA - 824: 11,12 - for connection of current circuits, $B 1-B 4$ - for connection of voltage circuits, $B E$ - for connection of earthing

For this purpose, the instantaneous values of voltages from all windings, and the primary and secondary currents were measured in operational mode of the transformer close to nominal. The mean value of the inductance of the primary winding of the transformer $L_{1 a v}$ was calculated by means of Eq. (5). Then, the choke with the known choke inductance value $L_{c h}$ measured by precise instrument was installed to series with the primary winding. Then, the testing of the instantaneous values of voltages from all windings and the primary and secondary currents were repeated; the mean value of the primary winding inductance for the given period of time $L_{1 a v}^{\prime}$ was determined using Eq. (5); the choke inductance value was calculated using expression $L_{\text {ch.c }}=$ $L_{1 a v}^{\prime}-L_{1 a v}$. Test results were statistically processed after 5-7 cycles (Korenko et al., 2013).

\section{Results and discussion}

Experiment results are shown in Fig. 3. There is a description of inductance dependences of the choke, which was processed using $L_{c h}$ - value of choke inductance calculated from the choke inductance by means of algorithm; $L_{c h . c}-$ value measured by a precise instrument; and $L_{\text {h.c. }}-$ value of the winding inductance of the transformer measured in the short circuit experiment in accordance with IEEE (1995).

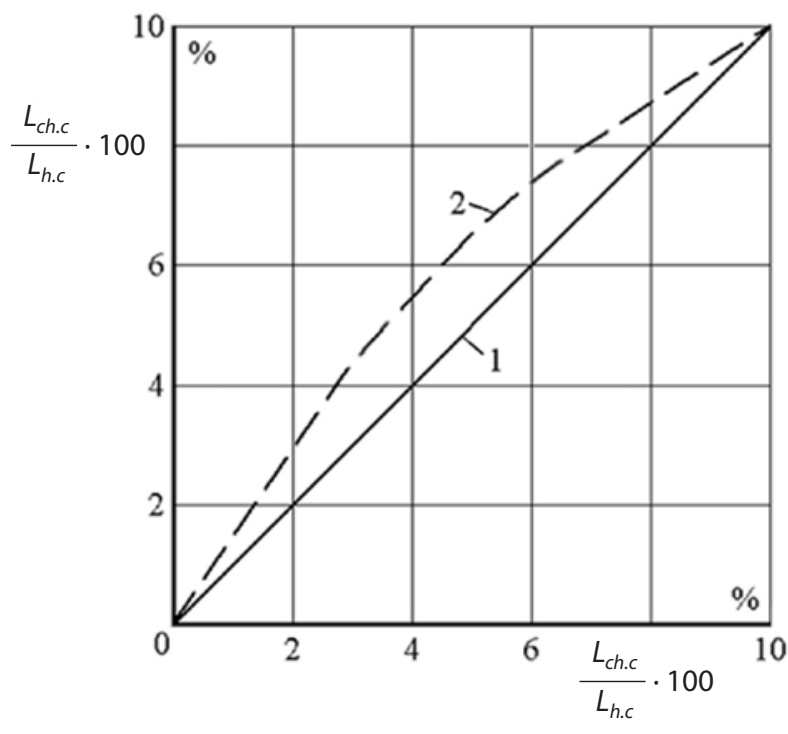

Fig. 3 Diagnostics results of windings deformation of singlephase power transformer with unloaded tertiary winding in operational mode: direct curve 1 - ideal; curve 2 - experimental

In regards to the changes in the choke inductance $L_{c h}$ depending on the transformer winding, $L_{h \cdot c}=1 \div 8 \%$, the error rate (the difference between straight line 1 and curve 2 ) did not exceed $2 \%$ in average. The data allow recording insignificant changes in the inductances of the windings, and thus also changes in inductive resistances of the windings. This leads to the conclusion that it is possible to monitor the winding deformation in single-phase power transformer with an unloaded tertiary winding in operational mode.

The results are consistent with the research of Russian scientists Khrennikov and Shlegel (2004), as well as foreign scientists Bengtsson and Abeywickrama (2012). The task of performing the diagnostics of the winding deformation in vital transformers in rural distribution networks is considerably beneficial from the economic perspective if it is taken into account that this task requires only usage of 
the simple algorithm and electric power quality analyzer PQA - 824, which can be also used for other measurements.

\section{Conclusions}

Laboratory tests proved that it is possible to diagnose the winding deformation in single-phase power transformer with an unloaded tertiary winding in operational mode by means of the algorithm proposed in the paper.

It is possible to diagnose the deformation of the windings for each phase of the three-phase transformers with unloaded windings in such a manner.

The electric power quality analyzer PQA - 824 can be replaced by another similar device.

In the transformer substations lacking the current and voltage transformers, it is necessary to install additional current and voltage transformers.

\section{References}

BENGTSSON, T. - ABEYWICKRAMA, N. 2012. On-line Monitoring of Power Transformer by Fundamental Frequency Signals. SIGRE. A2-110.

CAN, C. - LIN, X. - LI, X. 2016. Research on online monitoring of transformer winding deformation state based on short circuit reactance. In China International Conference on Electricity Distribution 2016. Xian, China, pp. 2010-2013. ISBN 9781467390712. CHEN, W. - SUN, C. - YUN, Y. 2002. Study on the recognition of transformer winding deformation by using wavelet transform in the LVI method. In International Conference on Power System 2002. Kunming, China, vols. 1-4, pp. 1966-1969. ISBN 0780374592.

DAVIDENKO, I. V. - KOMAROV, V. I. - TIKHONOV, A. A. 2008. Questions of reliability and diagnostics of power transformers of low voltage classes. In The Third Scientific and Practical Conference "Diagnostics of Electrical Installations" of the Public Council of Specialists of Siberia and the East on the problems of diagnostics of power electrical equipment and analytical instruments for energy enterprises and experience of their application 2008. The City of Angarsk. (In Russian: Voprosy nadezhnosti i diagnostiki silovyh transformatorov nizkih klassov napryazheniya).

DOROZHKO, S. V. 2011. Detection of deformation of windings of power transformers using the electric power quality analyzer PQA 824. In Electromechanics, no. 5, pp. 26-29. (In Russian: Vyyavlenie deformacii obmotok silovyh transformatorov s ispol'zovaniem analizatora kachestva elektricheskoj energii AKE-824).

DOROZHKO, S. V. 2015. Diagnosis of a single phase power transformer in operating mode. In Electromechanics, no. 1, pp. 4952. (In Russian: Diagnostika odnofaznogo silovogo transformatora $\checkmark$ rabochem rezhime).
DOROZHKO, S. V. - DUBKOV, A. N. 2010. The program for allocating the first harmonic components of information signals of the electrical network. In Methods and Technical Means of Increasing the Efficiency of the Use of Electrical Equipment in Industry and Agriculture: collection of scientific papers Stavropol. AGRUS, pp. 100-102. (In Russian: Programma vydeleniya pervyh garmonicheskih sostavlyayushchih informacionnyh signalov elektricheskoj seti).

IEEE Std 62-1995. 1995. Guide for diagnostic field testing of electric power apparatus - Part 1: Oil filled power transformers, regulators, and reactors.

HT-ITALIA. 2007. Electric power quality analyzer PQA - 823, $\mathrm{PQA}-824$.

KORENKO, M. - KAPLÍK, P. - BUJNA, M. - PRÍSTAVKA, M. 2013. Statistical process control in automotive industry. In Acta Technologica Agriculturae, vol. 16, no. 2, pp. 39-42.

KHRENNIKOV, A. Y. - SHLEGEL, O. A. 2004. Monitoring the change in the inductive resistance of the transformer to determine the damage in the windings. In Energy, no. 2. pp. 27-30. (In Russian: Kontrol' izmeneniya induktivnogo soprotivleniya transformatora dlya opredeleniya povrezhdenij v obmotkah).

MAKAROVA, N. L. 2012. Development of a method and technical means of diagnostics of isolation of power transformers of rural electric networks: the dissertation author's abstract.

MIYAZAKI, S. - MIZUTANI, Y. - TAGUCHI, A. 2017. Diagnosis criterion of abnormality of transformer winding by frequency response analysis (FRA) - Urgent diagnosis of turn short and heavy deformation. In Electrical Engineering in Japan, vol. 201, no. 3, pp. 3-13.

PRÍSTAVKA, M. - BUJNA, M. 2014. Monitoring the capability of production equipment in organization. In Acta Technologica Agriculturae, vol. 17, no. 2, pp. 39-43.

REDDY, P. A. - RAJPUROHIT, B. S. 2014. On-line monitoring of winding parameters for single-phase transformers. In India International Conference on Power Electronics. Kurushetra, India. ISBN 9781479960453.

XU, D. - LI, Y. 1998. A simulating research on monitoring of winding deformation of power transformer by on-line measurement of short-circuit reactance. In International Conference on Power System Technology. Beijing, China, vols 1-2, pp. 167-171. ISBN 0780347544.

ZASYPKIN, A. C. - DOROZHKO, S. V. 1995. Zero-phase equivalent circuit of an asymmetrical transformer as a model for diagnostics of winding deformation. In Electricity, no. 9, pp. 13-16. (In Russian: Skhema zameshcheniya nulevoj posledovatel'nosti nesimmetrichnogo transformatora kak model' diagnostirovaniya deformacii obmotok). 